\title{
THE UNESCO SITE “VENICE AND ITS LAGOON": CULTURAL HERITAGE PROTECTION POLICIES
}

\author{
F. Trovò 1 , * \\ ${ }^{1}$ MIBACT, Phd architect - francesco.trovo@beniculturali.it
}

Commission II - WG II/8

KEY WORDS: Venice, World Heritage List, Threats, Cultural heritage management, Ministry of cultural heritage, Mass tourism

\begin{abstract}
:
The paper focuses on cultural heritage protection policies for the Unesco site of Venice and in particular on recent actions and guidelines carried out and elaborated by the Superintendence for Archaeology, Fine Arts and Landscape for the City of Venice and Lagoon, one of the leading stakeholders in the protection of the site. The paper also highlights the negative impact of social and anthropological factors on the cultural heritage and identity of Venice, especially in areas with minor architecture, outside major tourist routes. It illustrates the social and technical transformations in construction, trade, housing, historical and their impact on the cultural heritage and landscape and considers potential strategies that address these concerns. It further examines the specific problems and obstacles that hinder these policies, evidencing how they can only be addressed through targeted actions by the municipal administration and other stakeholders.
\end{abstract}

\section{INTRODUCTION}

Venice and its Lagoon has been on the list of UNESCO World Heritage Sites since 1987. Since then many resources have gone into the protection of the site and in research on methods and practices for the sustainable conservation of the city. Since 2011, the writer has been the contact person for the UNESCO Venice and its Lagoon Site Office.

The Municipality of Venice has established a special office to the coordination of the activities of the Site. It is the responsibility of this body to convene periodic meetings of the Site's members and to coordinate the drafting of the Site Management Plan "Venice and its Lagoon", as requested by UNESCO in 2002 and by the Italian State in 2006. The Plan was drawn up between 2009 and 2012 and, as already noted, involves numerous stakeholders in various capacities active in the governance of the territory. Taking into account the current management and planning methods and the complex critical issues that characterize the Site, the Plan establishes a management system consistent with the values that motivated the Site's inclusion in the World Heritage List. Its role is to examine current change factors, identify future objectives, assesses possible impacts on local system, elaborates Action Plans to achieve these objectives, define coordination and implementation methods, and verify the achievement of objectives by systematically monitoring a series of indicators over time. The Plan thus represents a strategic tool for general guidance to assess, predict and manage the natural and manmade factors and processes of transformation that may affect the quality of cultural heritage recognized as universal heritage of humanity (Basili, De Vettor, 2014).

Since the establishment of the Plan, on the basis of a 2007 convention, the stakeholders have held periodic meetings in order to identify and adopt measures to counter threats to the site values identified in the Plan, such as the pressure of mass tourism, the increase of lagoon pollution, the transit of cruise ships in the lagoon, the social transformation of the ancient city, the transformation of historical buildings.

The results of these actions were considered insufficient by the mission carried out in 2015 by the commissioners appointed by UNESCO and this judgement was confirmed at the annual meetings of the World Heritage Committee in the following years, so much so that the Venice site and its lagoon is likely to be declared among the sites in danger.

\section{RESEARCH AND STUDY ACTIVITIES ON THE EXTERNAL COMPONENTS OF HISTORICAL BUILDINGS}

A number of useful studies have been carried out to identify good practices for interventions on traditional historical building, such as doors and windows and plasters. In particular, a book has been published on Venetian windows and doors (Trovò, 2013) and another on historical building plasters (Doglioni et al., 2017). The latter study is the result of a collective effort by people with different areas of expertise, such as architects, craftsmen and technicians of the City of Venice. The focus has been to identify intervention procedures that are not already covered by specific regulations and do not fall under the responsibility of the Superintendence.

One problem, in particular, concerns the external finishing of buildings. Based on Italian regulations, in the absence of a monumental protection measure (which applies only to 3,000 out of 20,000 buildings in Venice) interventions on external finishing are classified as ordinary maintenance and as such are scarcely regulated. On the other hand, these studies have evidenced the importance of external finishing for the perception of the historical urban landscape. As a result, specific sector regulations by the City of Venice for interventions on historical buildings have been drafted, foremost amongst them the Abaco degli Interventi (Abacus of Interventions).

\footnotetext{
* Corresponding author
} 
Following are two of the more relevant passages in the Abaco: door and window frames, if they are of interest on account of the historical significance of the building material (such as for example the presence of roller or cast glass, solid wood frames, the presence of wooden strips, seals, hardware,) must be recovered or replaced with elements that do not detract from the quality of the frame, and improve its performance from the point of view of efficiency and energy conservation; if not recoverable or lost, they must be made in accordance with the shape, size and type of traditional frame profiles. In particular, it is forbidden to replace double-sash windows with single-sash windows in traditional window holes, i.e. rectangular windows more than $80 \mathrm{~cm}$ wide (short side parallel to the floor), and to replace the original wooden doors with glass gates or doors or with reflective surfaces; interventions on windows and doors using different materials and shapes may one exceptionally be permitted, also for the purpose of improving hygiene and health, subject to the mandatory prior opinion of the Authority identified by state regulations; in any case, the use of anodized aluminum and plastic materials for the external parts of window and door frames and of mirrors and reflective glass is forbidden; the frames must remain in their original position with respect to the edge of the masonry; $[\ldots]$

Antique finishes, historical or traditional plasters must be preserved where possible; they must be replaced with mortar and components similar to the initial ones or in any case consistent with the nature of the building's facade, and using techniques typical of the context of the Historic Old Town, in use before the industrialization of lime and cement. In general, the thickness of the new plaster and its texture must be consistent with the characteristics of the masonry and of the elements present on the building front such as the frames of openings, stone or wooden inserts, etc., so as not to impair their legibility by making them too protruding or too recessed with respect to the plaster surface (Municipality of Venice, 2020).

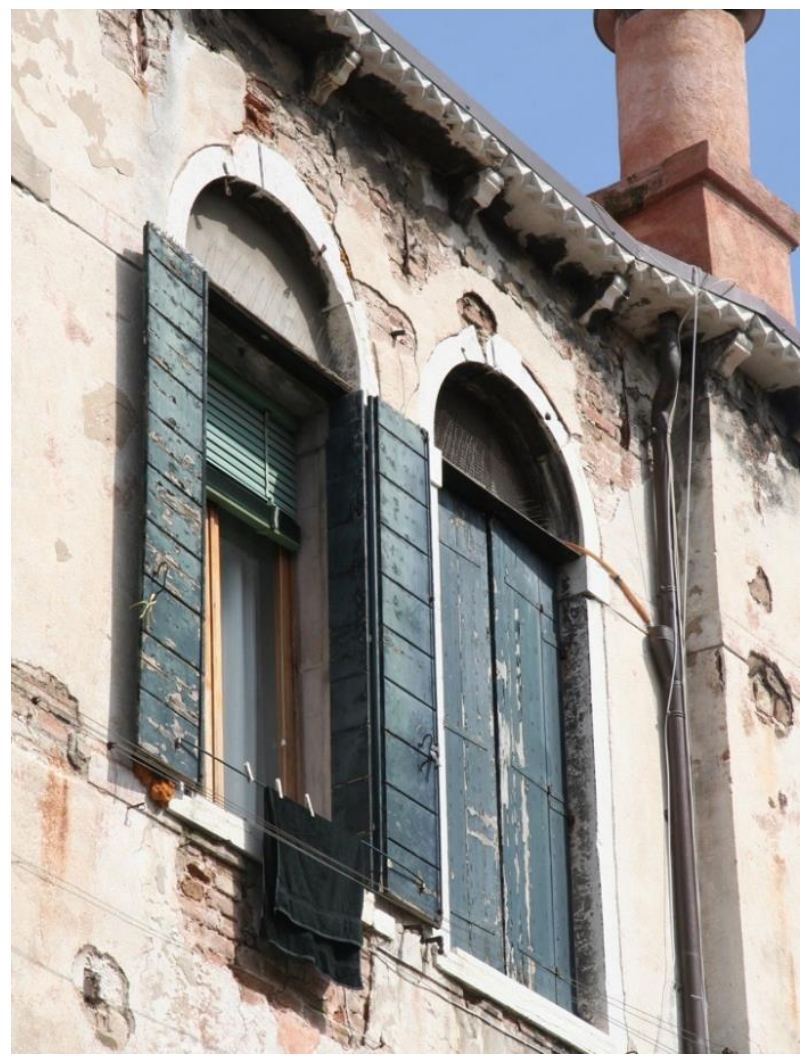

Figure 1. Windows of a historical building visible from a field of wells in the Castello district.
The Abaco also specifies that stone elements must be preserved if at all possible and replaced only in exceptional cases, using the same material. If a plaster has to be replaced, a permit is required not only to change the color, but also to change of the material, to counter the common practice of replacing old plasters with new ones, based on different materials and techniques, with the excuse of preserving or recreating the original color.

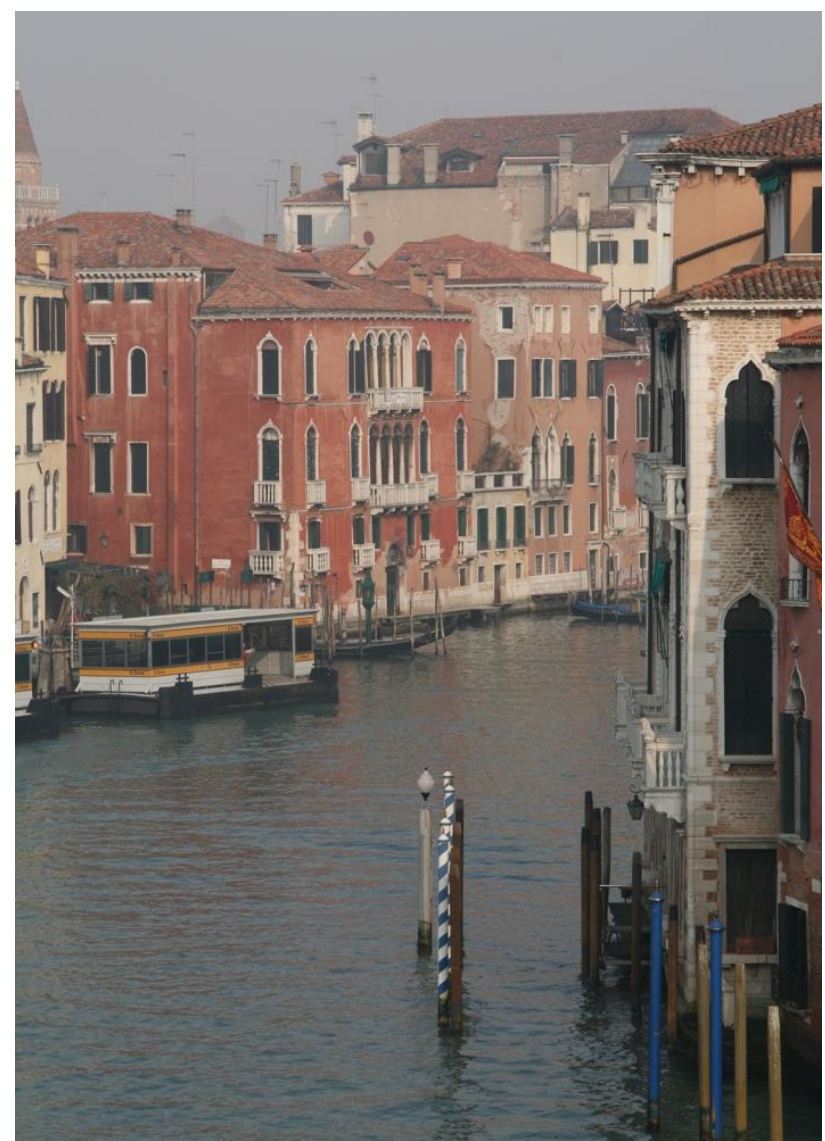

Figure 2. View of the building fronts with historical plasters in San Tomà on the Grand Canal.

The Superintendence has proposed to include among the "actions" of the Plan an "Evaluation of Wear and Tear Processes and Problems Caused by Mass Tourism in the City of Venice". In this regards, notes the following (Codello, 2014):

It seemed essential to resort to the need to elaborate and refer to a broad cultural idea with operational repercussions capable of truly assessing whether it is better to have a building that becomes a hotel or a building that deteriorates inexorably because there are no economic instruments to avoid it. It was considered fundamental that the Management Plan of the Unesco site should become an opportunity to think in terms of sustainability, so as to evaluate several factors at the same time, clarifying costs and benefits, disaggregating and re-aggregating available information and understanding, for example, that if we wish to keep the city alive and at the same time curb negative phenomena linked to the transformations in the use of buildings, we need to think about tools that allow us to face the enormous costs of restoration, so that these are not sustainable only by big firms intent on speculation. It seemed clear that the concept of 'degradation through notoriety' of buildings and areas of the city required improved definitions, or even new ones, to address the question, as did the classification of related wear modes (natural deterioration, obsolescence of components, social use). 
In particular, natural deterioration, to which it is also possible to attribute positive aspects, albeit in part, (in reference to the debate on surface cleaning, which should not be radical, or the preservation of oxalate patinas) is in contrast with entirely negative degradation phenomena from all perspective, due to lack of care but also to incongruous building interventions induced by changes in use or social adaptations. In this context, the idea of a research project that could hold together all these elements - and others - and also indicate the objective ways of identifying the risk for the conservation of the site, defining, in a word, the degree of 'wear' in the complex system of the city, and its physical and social meaning. (...)

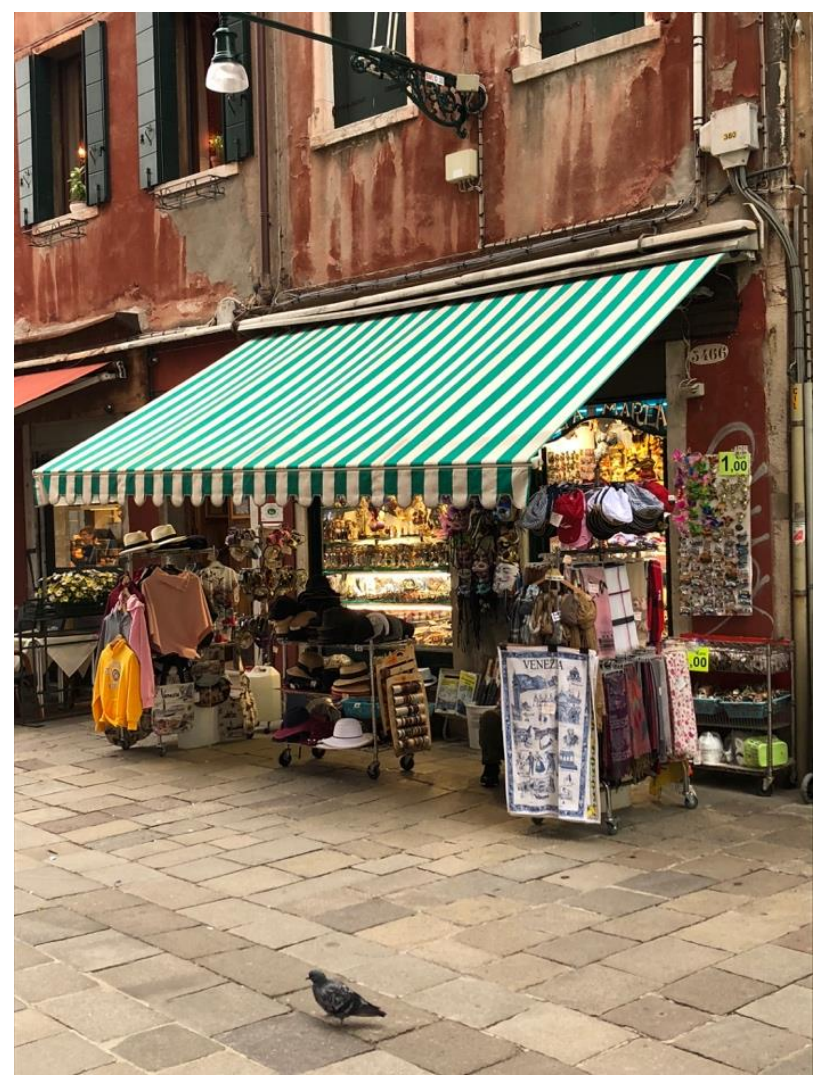

Figure 3. Shop in San Marco district. It is observed the occupation of public land with merchandise and the hanging of goods outside the shop windows (D. Perissinotto, 2019).

Among the most significant factors, investigated in the proposed initiative, there are, of course, those related to the tourist use of the city and its water and land use:ç

- public space deterioration due to excessive crowds (pavements, bridges, banks);

- progressive change in the use of buildings (hotels, B\&B, room rentals, timeshare, holiday homes);

- unbalanced specialization of commercial offer and services towards tourist demand;

- tendency to improper use of public space, with an increase in the number of occupations and the use of unsuitable furnishings;

- progressive erosion of the banks due to increased wave motion;

- degradation of structures in the vicinity of landing areas;

- progressive increase in the static vulnerability of buildings with canal bank walls.
At the end of March 2020, a second research project (Gasparoli, Pianezze, 2020) was completed aimed at identifying forms of mitigation of the wear phenomena highlighted in the first research mentioned above.

The research was financed by MIBACT under Law 77/2006 for the UNESCO Site "Venice and its Lagoon". The results of the project were communicated to the Municipality of Venice.

Participants included Paolo Gasparoli (appointed professional), arch. PhD Fabiana Pianezze (scientific collaborator), arch. Chiara Parolini, arch. Martina Pizzuti, Dr. Isacco Boffi (collaborators).

Also in this case, the Superintendence has had crucial role in identifying the main issues to be addressed.

The method of analysis developed in the previous research carried out between 2013 and 2014 was replicated for the investigations currently underway, identifying in detail the peculiar aspects of the phenomena described, and, at the same time, offering an overview that of the complex dynamics that make Venice unique. The study focuses on the three factors previously agreed upon with the Directorate for Strategic Projects and International and Development Policies of the Municipality of Venice and with the Superintendence, which have had a particular impact on the Venetian system, namely: occupation of public land; residential areas; maintenance of building fronts and pavements (based on the Activity Report from the date of the appointment until 29 January 2019).

\section{INSTITUTIONAL ACTIVITY}

A large part of the activities carried out by the Superintendence in the protection and management of the UNESCO Site of Venice are part of its institutional activities. These include direct actions, in which when restoration work is carried out directly by the Superintendence, whose officials play the role of Designers and Project Managers, and indirect actions in which the role of the Superintendence is to assess projects proposed by private Following is a list of the monuments in which projects have been carried out using State resources in collaboration with the International Committees for the Safeguarding of Venice: Marciana National Library, State Archive, Jesuit Church, Squero del Bucintoro near Arsenale, Saints John and Paul Church, Saint Salvador Church, Church of Santa Maria Maggiore, Doge's Palace, Nagger House; Accademia Museum; Procuratie Nuove, Quarto d'Altino archaeological area.

The Superintendence also, in line with the Code of Cultural Heritage, has highlighted the possibility of using poster advertising to fund the restoration of ecclesiastical goods: Church of San Simeon Piccolo, Church of the Barefoot, Church of San Bartolomeo, Church of San Moisè, Church of San Salvador, and St. Mark's Square, Bridge of Prisons. Of course large format advertising in important areas of the city is not an ideal solution, but this is often the only way to fund intervention on the 80 churches of the city, all in need of continuous maintenance.

Among the various financing forms supervised by the Superintendence mention should also be made of the numerous donations, in particular by the Private Committees for the Safeguarding of Venice, which have given been giving large sums to the city of Venice since 1966 to finance the restoration buildings and works of art. 

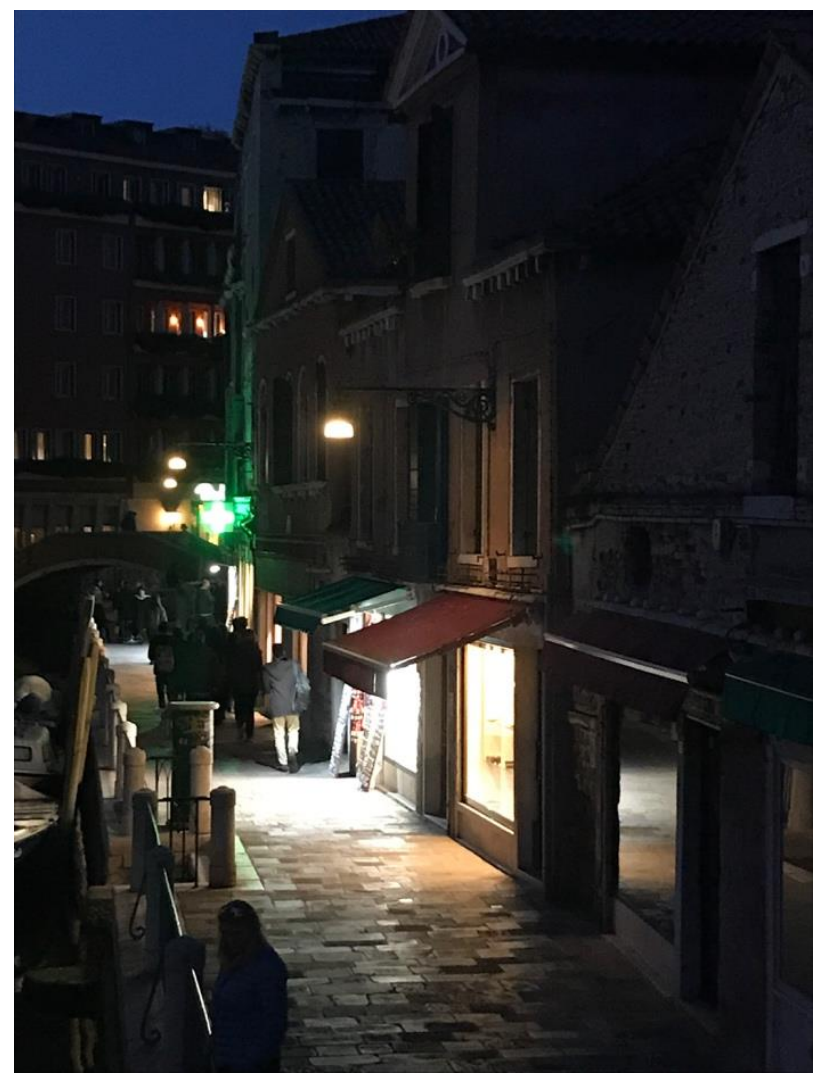

Figure 4. Shop in Santa Croce sestiere with very intense lighting compared to the context (D. Perissinotto, 2019).

As for other institutional activities related to the Site, the Superintendence in cooperation with the Municipality of Venice, is also working on the issue of commercial activities in culturally important areas and buildings, as per art. 52 of Legislative Decree no. 42 of 22 January 2004 (Cultural Heritage Code). The people who have dealt in particular with this theme, besides the author, are T. Favaro, A. Chiarelli and I. Cavaggioni.

The theme is very important because in recent years Venetian public spaces, also due to the constant increase in tourists, have been beset by stalls, leading to overcrowding and loss of visibility of the cultural heritage.

Altogether in the Municipality of Venice there are about 1,400 authorizations for "occupations of public land," of which 1,200 relative to the ancient city (tables and awnings for bars and restaurants, isolated souvenir stands, fixed trade displays, kiosks and newsstands).

After 2004 the Superintendence defined with the Municipality of Venice the list of areas to be excluded from any stalls concessions and those for which plans for stalls concessions must be drawn up.

Since 2006, the studies on the occupation of public spaces in the ancient city have accelerated significantly: by 2010, about 60 areas between Campi, Fondamenta and Calli were identified. For for about 40 of these, characterized by higher tourist presence, the City Administration has prepared 40 plans, which identify the level of public land occupation considered compatible with the protection of the cultural heritage and the management of pedestrian flows. For areas not subject to this type of planning, the Superintendence together with the Municipality has drawn up specific land use regulation.
In line with the activity in progress, since 2016, the Municipality of Venice has reiterated the commitments made, in order to ensure an update of the areas already covered by the Plan and to start the evaluation of those for which new drafting was considered essential.

Special attention has been paid to a review of commercial occupations on public land, in view of a reduction in the number of structures (commercial stands will be reduced by $61 \%$, souvenir stands by $36 \%$; in other cases, there are plans to move stands to less crowded areas or to rotate them); to the conversion of fixed kiosks to removable structures; to the introduction of a standard for structures, in order to reduce their size and facilitate control operations by the Municipal Police.

In 2018, a new Food and Beverage Regulation was introduced, which includes a ban on new activities in the old city.

As part of the activities carried out in collaboration with the Municipality of Venice, a reorganisation and redevelopment plan for the Rialto market area was launched at the end of the 1990s and was completed in 2017.

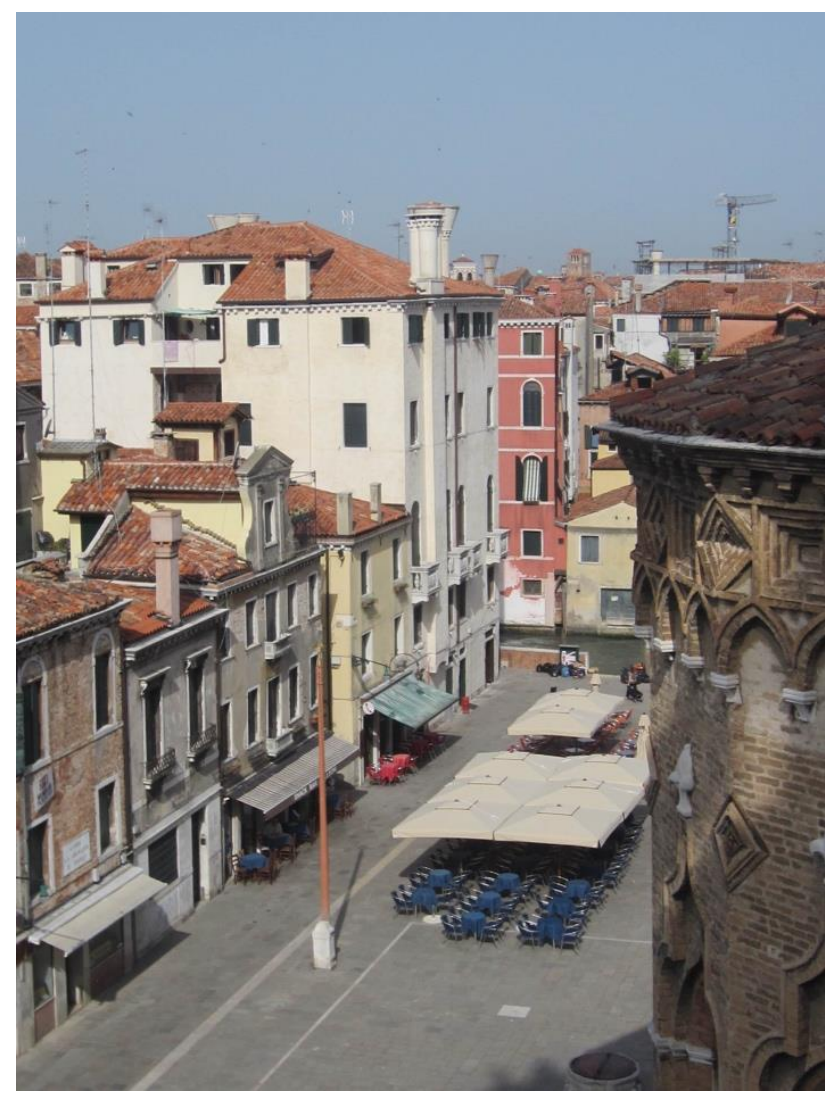

Figure 5. View from above of Campo San Giovanni e Paolo with seating and tables for bars and restaurants.

Another issue on which the Superintendence has been involved is the decorum of urban public spaces. Following an indication from the Superintendence, a provision has been included in the Urban Police Regulations prohibiting to hang wares outside the shop windows. Another prohibition concerns the use of lighted signs, in order to preserve the picturesque nocturnal atmosphere of the ancient city (Trovò, Turri, 2020). Other measures cover interventions on ancient pavements, mainly made up of trachyte masegni from the Euganean hills, one of the traditional features of the Venetian cultural heritage that must be preserved. 
An intensification of controls and sanctions by the Municipal Police is deemed necessary; in this perspective, it would be desirable to increase fines and also to draw up new regulation on street fixtures, including signs and other forms of advertising, to ensure a more effective and coordinated action protection the decorum of the ancient city.

As part of the protection activities carried out in 2019, presented to the UNESCO Commissioners during the Advisory Mission held in Venice from 27 to 31 January 2020, there are the measures carried out by the Superintendence issues in compliance with the Cultural Heritage Code. These included:

- 71 checks of cultural interest (articles 10 and 12);

- 15 declarations of cultural interest (articles 13 and following);

- 971 authorisations for intervention projects on cultural heritage (art. 21);

- 338 authorizations for posters and advertising (art. 49);

- 25 inspections for disposal authorizations (art. 54 et seq.);

- 176 pre-emption actions (art. 59);

- 395 authorizations for archaeological material;

- 4,081 opinions for landscape authorisations (art. 146).

Finally, a number of measures have been taken for the protection of typical historical lagoon vessels.

The of activity and its quantification for 2019 have been illustrated by architect Emanuela Carpani, Superintendent of the Institute since 2015.

\section{CONCLUSIONS}

With the exception of issues which pertain to the State, such as the issue of Big Ships and High Water Defence (Mo.S.E.), or other environmental issues such as the defence of the lagoon from the risk of irreversible morphological changes, and environment and pollution issues, which are the responsibility of the Province and the Region most of the issues relating to the management of the UNESCO site Venice and its lagoon which affect the architectural heritage and the urban construction system of the ancient city and lagoon are the responsibility of the Superintendence which, with considerable commitment in terms of staff and resources, is actively pursuing the goal of preserving the site from the inevitable threats affecting it.

In the study dealing with plasters and external wall surfaces in Venice mentioned above (Doglioni et al., 2017, p. 19-21) the hope was expressed that the regulatory review process would take into account the results of the studies conducted.

The study does not aim to prefigure a prescriptive regulation in itself, let alone a "colour plan", which seems neither possible nor appropriate in Venice. The variability, the coexistence of different and differently preserved and restored artefacts, the different interpretations that over time have been given, through the surfaces of the façades, of the "Venetian character", cannot be reduced to a single criterion, let alone by a palette of colours.

This would risk cancelling out the strongly expressive materiality of Venetian masonry and stones, making the "image of Venice" the fruit of a composite perception and reading, of which colour is only one component. Not a single criterion, therefore, but an articulation of criteria corresponding to the thematic variety of Venice. This variety could be based on a reference case history, in order to make the criteria and the interventions comparable in the case of data relative to the architectural features and the condition of the artefact.
In particular, the Abacus of the Interventions echoes the redefinition of transformations in building with landscape value contained in art. 146 of Legislative Decree 42/2004, providing a precise guideline for those who have intervene on building facades.

To this we must add the important innovations introduced through the Building Regulations of the City of Venice in 2020, which takes up the indications contained in the study, listing mandatory rules that protect plasters, windows and stone parts (Municipality of Venice, 2020).

It remains to be seen whether it will be possible to translate these important criteria for regulating the treatment of the external parts of buildings into the Landscape Plan.

Another important question at the level of public funding concerns the support by the Italian state to private interventions, which until a few years ago did not take consider to rewarding the more conservative interventions, thus favouring inappropriate transformations (Trovò, 2010).

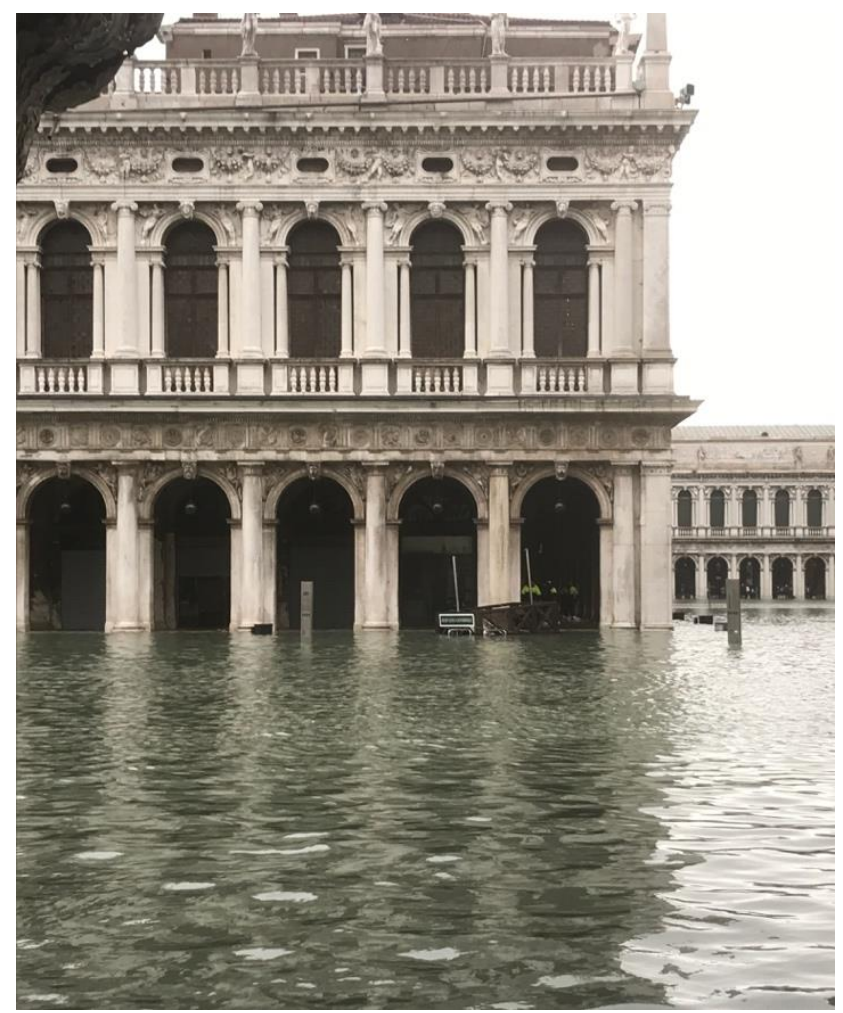

Figure 6. View of the Marciana National Library in St. Mark's Square the morning after the high water peak of November 12, 2019.

In conclusion, a few words on the high water that hit the lagoon and the city of Venice on 12 November 2019, with a peak of 187 $\mathrm{cm}$ above sea level, the second ever since 1966. The Italian Ministry for Cultural Heritage and Tourism (MIBACT) immediately nominated an emergency management coordinator at the Veneto Regional Secretariat. The Superintendence prepared a damage report based on information received from property owners and, as soon as possible, carried out inspections to verify the damage in buildings subject to cultural protection measures. This episode demonstrated once again the fragility of the system and the need to urgently implement protection policy for Venice, establishing regular fundings and rewarding conservation efforts in the allocation of resources. 


\section{ACKNOWLEDGEMENTS}

Special thanks to arch. Renata Codello, who was the first to strongly believe in the role of the Venice Superintendence in pursuing the objectives set by UNESCO for the protection of the city, as well as to the current Superintendent Architect Emanuela Carpani who has continued to trust in me as a reference point for the UNESCO Site Venice and its lagoon.

A special thanks to the UNESCO Office of the Municipality of Venice, to the architect Katia Basili, who supported the activities making possible a fruitful exchange between different subjects. Finally we would like to thank Prof. Paolo Gasparoli of the Politecnico of Milan and all his research staff for contributin to the study of the problems of Venice with dedication and competence, obtaining excellent research results.

\section{REFERENCES}

Basili, K., Codello, R., Gasparoli, P, Ronchi, F., Pianezze, F, Totaro, G., Trovò, F., 2013: Wear processes in architectural heritage: definition, studies, contrasting measu-res. The case of UNESCO World Heritage Site "Venice and its Lagoon", Online Proceedings of Conference Built Heritage, Milan

Basili, K., De Vettor, G., (edt.), 2014: "Venezia e la sua Laguna" Patrimonio Mondiale Unesco. Piano di Gestione 2012-2018, 3b press, Venice

Codello, R., Gasparoli, P, Ronchi, F., Pianezze, F, Totaro, G., Trovò, F., 2014: Tutelare il centro storico di Venezia. Una lettura integrata dei processi di usura fisica e percettiva per la definizione delle azioni di mitigazione. Journal of Technology for Architecture and Environment, 7, 75-80

Codello, R., 2014: Presentazione, in Gasparoli, P., Trovò, F., Venezia fragile - Processi di usura del sistema urbano e possibile mitigazione, Altralinea, Florence, p. 10-11

Doglioni, F., Scappin, L., Squassina, P., Trovò, F., 2017: Conoscenza e restauro degli intonaci e delle superfici murarie esterne di Venezia. Campionature, esemplificazioni, indirizzi di intervento, Il Prato, Padua

Gasparoli, P., Trovò, F., 2014: Venezia fragile - Processi di usura del sistema urbano e possibile mitigazione, Altralinea, Florence

Gasparoli, P., Pianezze, F., 2020: Strategy for sustainable tourism in Venice and its Lagoon: management, mitigation, awareness raising. The research was completed at the end of March 2020 and was delivered to the Municipality of Venice.

Municipality of Venice, Urban planning sector, Standard Building Regulations of the Municipality of Venice, 2020, art. 71, item 6.1 and 6.2 (web: https://www.comune.venezia.it/it/content/regolamento-ediliziocomune-venezia-0)

Trovò, F., 2010: Nuova Venezia antica, 1984-2001- L'edilizia privata negli interventi ex lege 798/84, Maggioli, Rimini-Milano

Trovò, F., De Dato, P., 2013. Sobre la reciente tendencia de renovar las superficies de los edificios de Venecia. Loggia arquitectura \& restauratión, 24-25, 44-57
Trovò, F., (edt), 2013: I serramenti dell'edilizia storica di Venezia. Conoscenza e intervento, Il Prato, Padua

Trovò, F., 2017. Cuál Venecia. transformaciones y tutela mediante una investigación sistemática de las operaciones realizadas (1984-2001). Loggia - arquitectura \& restauratión, $30,08-19$.

Trovò, F., 2018: La tutela delle superfici architettoniche del paesaggio storico italiano. Osservazioni sul ruolo delle normatove di settore dopo il d.P.R. 31 del 2017, Atti del $34^{\circ}$ convegno internazionale Scienza e Beni Culturali: "Interventire sulle superfici dell'architettura tra bilanci e prospettive" (Bressanone), Arcadia Editore, Venezia

Trovò, F., Turri, A., 2020: L'illuminazione della città storica. Il caso di Venezia, Congresso Nazionale AIDI 2020, "La luce tra cultura e innovazione nell'era digitale, the contribution was accepted by the scientific committee of the conference, scheduled for next October

UNESCO, 1987, Decision CONF005 VII.A Inscription: Venice and its lagoon (Italy)m https://whc.unesco.org/en/list/394/documents/

UNESCO, 2014, Decision 38COM 7B.27 Venice and its lagoon (Italy) (C394), https://whc.unesco.org/en/list/394/documents/

UNESCO, 2015, Report of the joint World Heritage Centre/ICOMOS/Ramsar Reactive Monitoring mission to the property of Venice and its Lagoon (Italy), 13-18 October 2015, https://whc.unesco.org/en/list/394/documents/

UNESCO, 2016, Decision 40COM 7B.52 Venice and its lagoon (Italy) (C394), https://whc.unesco.org/en/list/394/documents/

UNESCO, 2017, Decision 41COM 7B.48 Venice and its lagoon (Italy) (C394), https://whc.unesco.org/en/list/394/documents/

UNESCO, 2019, Decision 43COM 7B.86 Venice and its lagoon (Italy) (C394), https://whc.unesco.org/en/list/394/documents/

UNESCO, 2019, Decision 43COM 8B.46 Venice and its lagoon (Italy) (C394), https://whc.unesco.org/en/list/394/documents/

UNESCO, 2019, Decision 43COM 8D Clarifications of proprety boundaries and aeras by States Parties, https://whc.unesco.org/en/list/394/documents/ 